Article

\title{
Exploring the Topics of Soil Pollution and Agricultural Economics: Highlighting Good Practices
}

\author{
Vítor João Pereira Domingues Martinho ${ }^{1,2}$ \\ 1 Agricultural School (ESAV) and CI\&DETS, Polytechnic Institute of Viseu (IPV), 3504-510 Viseu, Portugal; \\ vdmartinho@esav.ipv.pt \\ 2 Centre for Transdisciplinary Development Studies (CETRAD), University of Trás-os-Montes and Alto \\ Douro (UTAD), 5000-801 Vila Real, Portugal
}

Received: 11 December 2019; Accepted: 14 January 2020; Published: 19 January 2020

\begin{abstract}
The evolution of the agricultural sector around the world has generated positive and negative externalities at social, economic and environmental levels. These impacts from the modernization of agriculture would not be, themselves, problematic if the global balance were positive, in sustainable development. However, in some cases, the negative externalities overlap the positive outcomes, namely in soil pollution from the application of fertilizers and crop protection products. From this perspective, the main objective of this study is to explore the relationships between the two following topics: soil pollution and agricultural economics. For this a literature survey was performed from the Web of Science platform based on these two topics put together. From the Web of Science, 45 studies were found and were clustered and explored first through the software VOSviewer. The literature explored with this software was clustered into three groups and shows that the studies related with these topics highlight, namely, three aspects: the problem in question, the benefits and the losses. After this network analysis, the several documents were studied deeper through literature review. Agricultural policies, farmers perceptions, stakeholders' involvement, farms' multifunctionality, sustainability and adjusted agricultural practices are all questions to be taken into account in the feedback between soil pollution and agricultural economics.
\end{abstract}

Keywords: literature review; soil health; farming performance; Web of Science; VOSviewer; clusters

\section{Introduction}

Amongst the various farming factors of production; the soil, its quality and characteristics play a determinant role for the performance of farms. However, nowadays soil pollution is a dramatic reality, due to several causes such as, for example, the evolution of societies, the modernization of the agricultural sector and the several policies designed for agriculture around the globe over recent decades. In fact, soil pollution is not only a consequence derived from agricultural activities.

The problems related with soil pollution are not only caused by direct impacts upon the soil quality, but also, from indirect implications on water quality and on human health, because of the chemical residues which pass on to food. Populations are now better informed about the implications of soil pollution (for example), namely due to health problems and, consequently, farmers search for perceived healthier practices, such as organic farming, however there is still a long way to go on both the sides of consumers and producers [1].

Of course, adjusted policies for all sectors having implications on soil quality should provide here a crucial contribution. The Common Agricultural Policy (CAP) form the European Union, for example, has several instruments in the first (more for the farmers' income support, namely through subsidies) and second (for the farm investment promotion, namely through structural financial support) Pillars, however it seems that in certain cases there is not enough to prevent soil degradation. In any case, 
the agricultural policy context from the European Union, in an environmental perspective, is much better today, than before the first CAP reform of 1992. This reform decoupled, namely, the subsidies from the level of production in farms and introduced environmental concerns [2].

In agricultural activities, the intensive application of chemical fertilizers and crop protection products seems to be the main causes of soil pollution, a solution for which appears to be difficult to find. Indeed, the agricultural sector survives on small profit margins, where it is crucial to maximize returns and minimize costs. In this difficult balance between incomes and costs, the options for farmers are very limited, specifically in a sector where the producers' prices are tend to already be low. Economic returns have, indeed, a determinant weight upon farmers' decisions [3].

This study may be an interesting contribution for the several stakeholders related with these topics, because it explores the several relationships evidenced by the studied literature related with soil pollution and agricultural economics (highlighted by the network visualization map). These insights could provide important support for the farmers and policymakers' (for example) decisions. On the other hand, the literature review made, considering this previous network analysis, allows to better explore the respective information behind, each document, by issue.

In this way, after this introduction, this study will be structured into five more main sections. The next section will investigate the several networks between the documents analysed, in the third part we will stress "what has been done and what has to be done", in the fourth section there will be a literature review to better explore the information behind the network analysis. In the fifth part good practices for soil quality (and the inherent benefits) will be highlighted and finally in the sixth section will be a presentation of the main insights.

\section{Network Analysis about Literature Related with the Two Topics: Soil Pollution and Agricultural Economics}

In this context, the aim of this study is to explore the literature related with the relationships between the two topics: soil pollution and agricultural economics. In order to do that, 45 scientific studies found in 2018 from the Web of Science [4] for these topics (soil pollution and agricultural economics) were analysed. These scientific studies were first explored and clustered through the VOSviewer software [5], creating a map based on text data and considering 4 as the minimum number of term occurrences. From here three clusters were found where the central terms (with greater importance/weight) appears (from a subjective visualization of the figure) to be "problem", "benefit" and "loss". Considering these clusters and the terms associated with each one, the several studies will subsequently be explored deeper through a literature review.

By analysing 45 scientific documents related with the topics of soil pollution and agricultural economics, considering the VOSviewer software, the map based on text data presented in Figure 1 was obtained.

In the VOSviewer software, for the network visualization, each item is represented by its label and by a circle. The dimension of the label and the circle depends on the importance of the item (number of occurrences in this study based on text data). The distance between two terms (relatedness) is indicative of the number of co-occurrences in documents. Finally, a set of items interrelated included in a map constitutes a cluster. Each item can belong to solely one cluster and the items of each cluster have the same colour [6].

It is worth stressing that in this study, comparatively with Martinho [7], for example, in terms of methodology, the information shown in each cluster has been exploited further, namely the idea of central terms and the respective relatedness with other terms.

From this analysis it was possible to find 3 clusters, where the items related with each cluster are the following:

- Cluster 1: benefit; biodiversity; combination; component; difference; economic incentive; efficiency; environment; environmental pollution; eutrophication; farm income; knowledge; need; nitrogen; objective; order; phosphorus; producer; productivity; term; yield. 
- Cluster 2: agricultural land; aquifer; case; change; country; economic return; food; groundwater; increase; problem; process; purpose; range; region; response; solution; sustainability; time.

- Cluster 3: agricultural practice; agricultural production; erosion; evidence; example; field; land; loss; nutrient; runoff; society; soil erosion; soil fertility; water quality.

Analysing deeper into Figure 1, in cluster 1 it appears to be the term "benefit" that interlinks with the remaining terms, in cluster 2 it appears to be the term "problem" and in cluster 3 it appears to be the term "loss". These interrelationships will be explored deeper in the following subsections and analysed further in Section 4. 


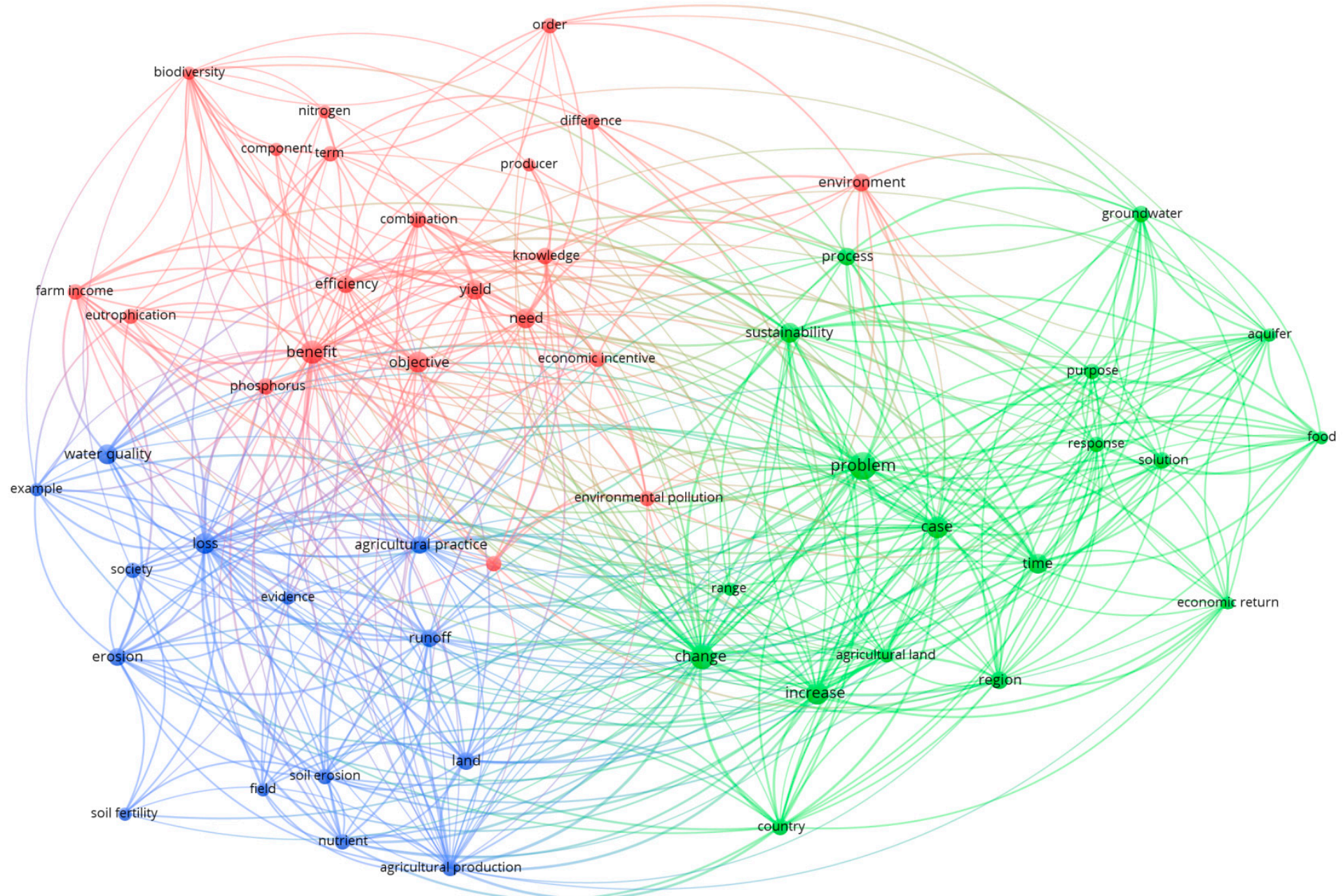

Figure 1. Map based on text data for 45 studies related with the topics: soil pollution and agricultural economics. 
2.1. Exploring Interrelationships to Improve the Benefits from Interactions between Soil Pollution and Agricultural Economics

Analysing Figure 2 and considering the term "benefit" as central in the several interconnections inside cluster 1, this word is more interrelated with terms from the same cluster such as: efficiency, objective and phosphorus (these terms are closer in the map). In a position which is not so close appear terms from cluster 1 such as, for example: knowledge, nitrogen, eutrophication, biodiversity and farm income. In a position, also, not so close, appear terms from cluster 2 such as, for instance, sustainability and change, or from cluster 3 such as water quality and agricultural practice.

In the interrelationships between soil pollution and agricultural economics, efficiency plays a determinant role here towards improving the benefits, as well as the definition of clear objectives and the management of some nutrients such as phosphorus. With less relatedness with the term benefits appear terms related with knowledge, farm income, sustainability, water quality and agricultural practices.

This shows that there is a long way to go towards improving the perception of the several stakeholders about the benefits of new technical and scientific insights and from sustainable plans of agricultural development. Where the biodiversity may be preserved and the different resources (including, for example, the water and nutrients) may be managed in a more adjusted way. 


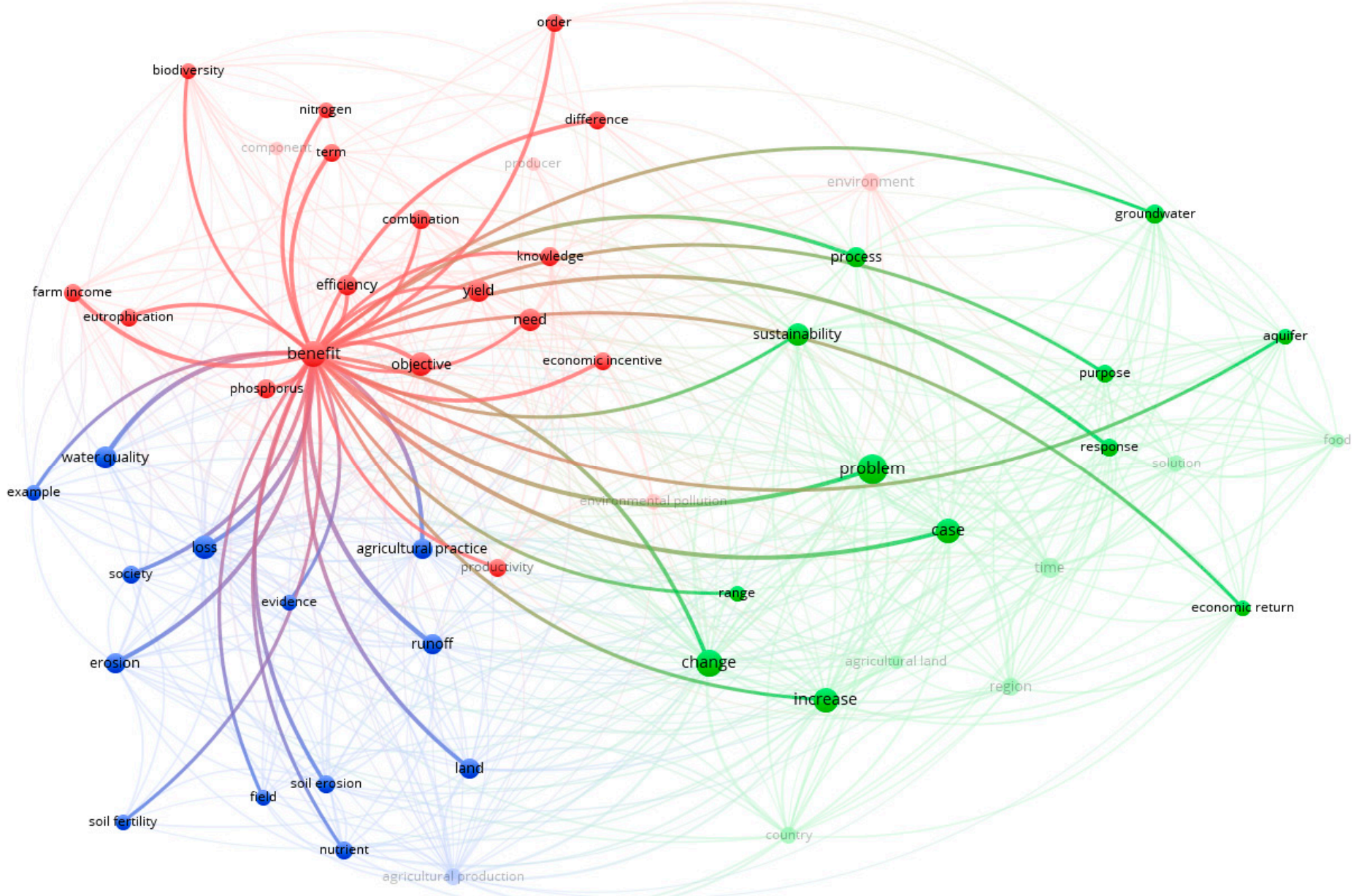

Figure 2. Interrelationships with the term "benefit" from cluster 1. 
2.2. Highlighting the Terms Related with Solutions for the Soil Pollution Problem, Namely in Terms of Agricultural Economics

Considering the term "problem" as being central inside cluster 2, Figure 3 shows that the closest terms in the map are words such as: case and sustainability. Not so close appear to be terms such as, for example (from the same cluster): change, increase, response, solution, region, agricultural land, purpose and process. Also, not so close, but from cluster 1 appear terms such as: environmental pollution.

These networks reveal that, across the several interrelations among soil pollution and agricultural economics there is a problem of sustainability that seems to be more regional than national for which it is important to find responses and solutions. In fact, there are changes needed, however the solutions and the responses seem to have little relatedness with the problems, or in other words, the scientific literature more frequently identifies problems within these interrelationships than highlight solutions and responses. On the other hand, little attention has been given toward stressing environmental pollution as a problem in the interrelationships between soil pollution and agricultural economics. 


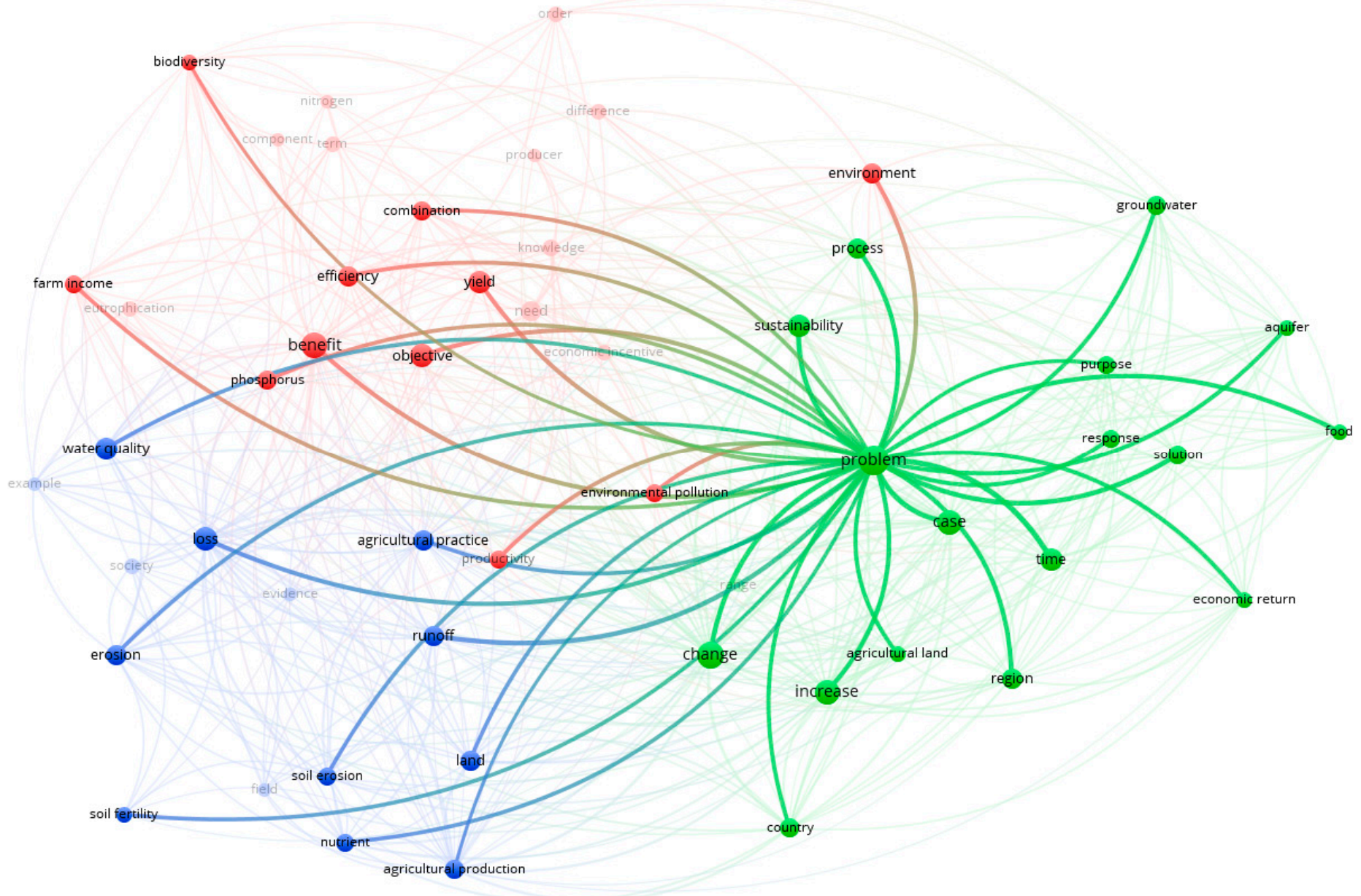

Figure 3. Interrelationships with the term "problem" from cluster 2. 
2.3. Stressing the Networks for Reducing the Losses between Soil Pollution and Agricultural Economics

From Figure 4 and considering the term "loss" as the term with more weight (in terms of occurrences), the closer terms in the map are society and evidence. Not so close appear terms such as, for example: water quality, agricultural practices, erosion and runoff.

Considering these terms as being those which are closer with the term with more occurrences, it would seem that the greater loss from the relationships between soil pollution and agricultural economics is for society. On the other hand, the perception about the loss of water quality and from erosion appears to be relatively weak, as well as the importance of agricultural practices to reduce the losses. However, agricultural practices, here, provide a crucial contribution towards reducing losses and improving benefits. In any case, the water quality and soil erosion look to be more related with losses than with benefits. This reveals that, in general, the several stakeholders seem to be more concentrated on the negative impacts from soil pollution in the water and soil quality than to highlight the importance of healthy water and soil for e society. In fact, the negative effects from the soil pollution in the human health, ecosystems and environment have implications upon the entire community. 


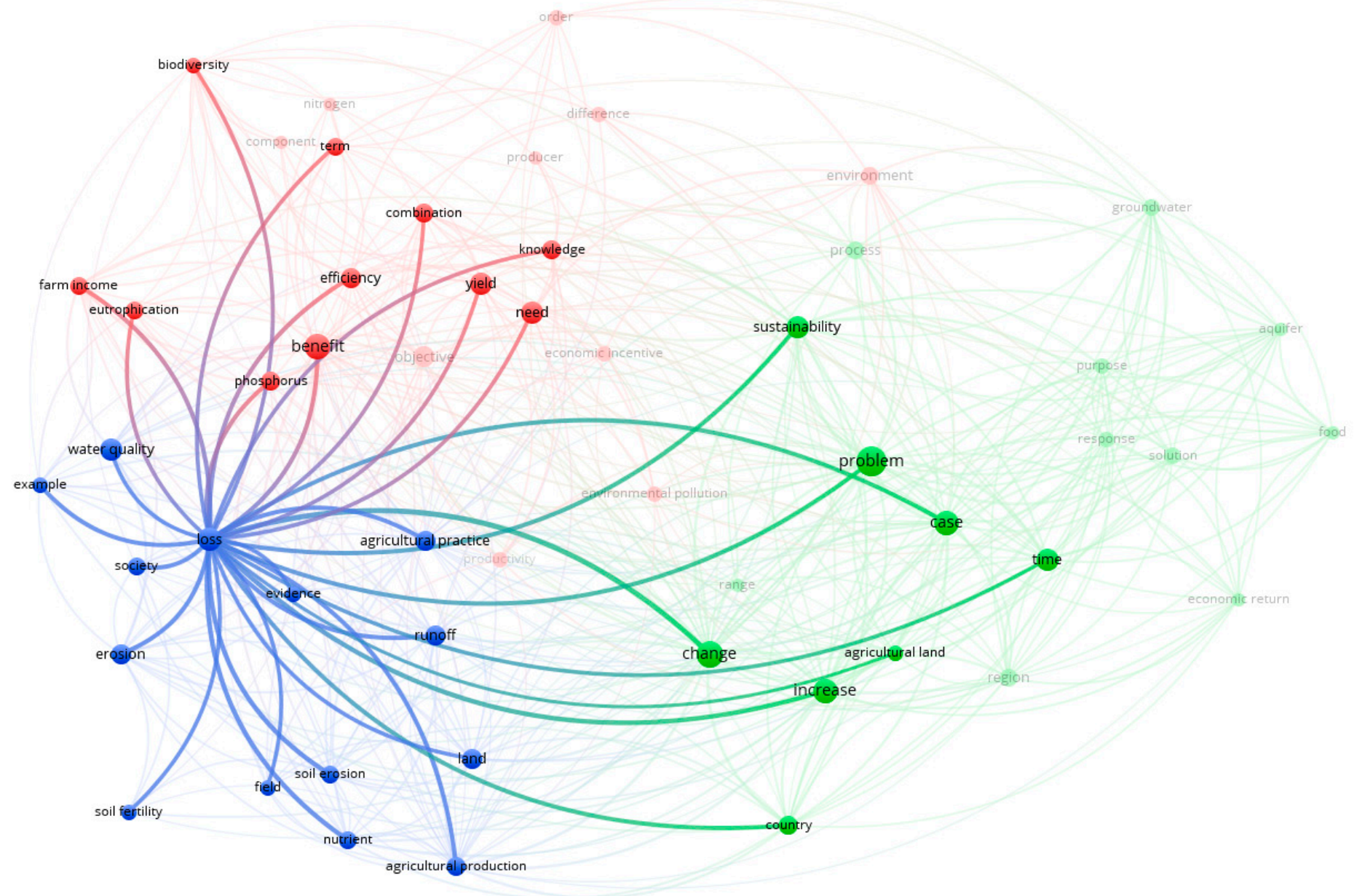

Figure 4. Interrelationships with the term "loss" from cluster 3. 


\subsection{Final Remarks from Network Analysis}

In conclusion, in the interrelationships between soil pollution and agricultural economics topics, there is, indeed, a problem of sustainability, for which it is urgent to find responses and solutions. However, the several stakeholders are more concentrated on the problems rather than on the solutions. On the other hand, it is important that the several stakeholders understand that, sometimes, it is more important to highlight the benefits from water and soil having high levels of quality than to stress, again, the negative impacts on the ecosystem and the community from water and soil pollution.

Agricultural practices may play a fundamental role here in order to improve, namely, efficiency and mitigate the main consequences, inclusively for society, on water quality and soil erosion. In fact, the soil is one of the most important factors of production in the farming sector, having several implications on the performance of agricultural economics. On the other hand, the options made by the farmers, namely in terms of agricultural practices, influence the quality of this factor of production which is interlinked with other factors such as water.

\section{What Has Been Done and What Has to Be Done}

Impacts on soil pollution from the agricultural sector, in all its dimensions, have been the main focus for several studies performed around the world. In fact, much work has already been done in these fields, stressing, for example, aspects related with environmental externalities, including nonpoint source pollution [8], efficient soil nutrient management [9], water quality [10] and the roles of the several stakeholders [11].

On the other hand, the great challenges for the future, in the issues related with implications of soil pollution from agriculture, will be, for instance, to find a balanced coexistence between environmental pollution management and ecological sustainability [12], the sustainable relationships among the economic and environmental dimensions [13] and the role of genetically modified plants in order to mitigate soil pollution [14].

However, considering the number of studies related with the several topics associated with soil contamination, in this study special relevance was given to the relationships between soil pollution and agricultural economics, constraining the focus from the scientific literature to these two fields. In addition, for a sustainable development, the several approaches driven to the questions related with the agricultural sector, including soil pollution, should take into account the economic dimensions, considering its importance in the decisions and perceptions of the farmers.

In order to bring more insights about these two topics in the next section there will be a further exploration into the different documents studied through network analysis on previous occasions. The insights highlighted with this study will bring about relevant contributions for the perceptions of the several stakeholders (including policymakers and researchers) about the relationships between soil pollution and agricultural dynamics. For example, it was emphasized that the scientific documents related with these two topics must give more relevance to solutions so as to mitigate the problems related with soil pollution from farming activities.

\section{Exploring Further Literature Associated with the Topics: Soil Pollution and Agricultural Economics}

Considering the cluster analysis outlined before, in this section the literature will be explored even further, by taking into account the number of clusters identified and the respective terms which are related with each one. From the 45 scientific studies in this section only 44 were analysed, because it was difficult to find, beyond the title, at the very least, even an abstract for the study developed by Willis [15]. There are another few cases where it was difficult to analyse the full papers, because they either do not exist or are available only under special subscriptions. 


\subsection{The Benefits from Agricultural Activities}

Agricultural policies play a determining role to reduce the impacts from farming practices on soil contamination, thus, improving sustainability and the interrelationships with the environment [16]. Agricultural policies, namely those from the Common Agricultural Policy (European Union), have been addressing these concerns. In fact, the CAP, namely since its reform in 1992, introduced effective instruments to improve the sustainability of the agricultural sector, specifically to promote, for example, integrated agricultural production, organic farming and the preservation of traditional production systems. The CAP also created, in 1992, incentives to maintain farmers in the mountainous and less favoured regions, with social and environmental objectives [17]. The agricultural activities developed through adjusted public plans may play an interesting contribution for sustainability, providing positive externalities.

The combat against soil erosion is another question where the agricultural policies designed at national and supranational level may support and give incentive for more environmental friendly practices [18]. For an effective achievement of the goals intended, the policies should be well designed and the related programs should be well managed [19]. In designing well-adjusted policies it is important to characterize the several sources of pollution and the respective behaviour for several strategies of mitigation $[20,21]$. The continuous assessment of policies is crucial for necessary adjustments in order to adapt to new realities and contexts [22]. Another important question about policy design is the involvement of the several stakeholders, namely the local communities. The commitment of the several stakeholders allows for collecting local and sectorial information and subsequently improving the implementation of the respective policy instruments [17]. This approach of involvement of the several interested parties mitigates the design of unadjusted policies and the resistance of the main addressees.

Productivity and efficiency are two important variables that should be maintained under control in farms so as to obtain contexts which allow for positive incomes for farmers and positive impacts on the several environmental dimensions [23]. Good performances for these variables in farms are particularly crucial, especially when the reduction in pollution from agricultural activities could result in farmers' net income decreases [24]. However, it is important to persuade the farmers to use sustainable practices to improve productivity and efficiency at medium and long-term scales [25]. In fact, sometimes, there is a lack of perception amongst farmers about the several implications from soil pollution and about the importance of sustainable practices. These contexts become worse when the dynamics in the farm is weak and the environment preservation implies reductions in the revenues and increases in the costs. In some circumstances the farmers' training and economic incentives may have interesting positive effects on the reduction of negative impacts from chemical production factors currently applied in farming [26]. The economic incentives from public institutions are completely justified by the social benefits from sustainable agricultural practices implemented by farmers, namely in terms of greater quality of water and for the agro-chain $[27,28]$.

\subsection{The Problems and Solutions within the Relationship between Soil Pollution and the Agricultural Sector}

An important question to be taken into account, in these contexts related with the problems and solutions in the interrelationships between agricultural economics and soil pollution, is about spreading the awareness to the several stakeholders that bad practices today as an attempt to improve the net farm profit, will have consequences on the revenues of the future [29]. It is important, also, that the several stakeholders understand that it will be vital to highlight and focus more on the solutions than on the problems and to greater stress the importance of good water and soil quality rather than the negative effects which occur from water and soil pollution. On the other hand, the implementation of strategies to mitigate the problems of context, such as erosion, is sometimes ignored, because of the high associated costs [30].

Sometimes, soil pollution from agriculture is not always a consequence resulting, only, from the use of chemical production factors (fertilizers, pesticides, ... ), but, often, it is also a consequence of 
the options taken related to other activities located upstream or downstream of the said agricultural activities, such as, for example, energy production [31]. In fact, it is important to refer that agricultural activities do indeed provide substantial contributions towards soil pollution, but are not the only parties who are guilty of this.

Never until today, has there existed so many solutions to the problems associated with the impact on soil pollution from agricultural activities, mainly as a consequence of the research developed over the last decades, namely by agricultural economists that explored the various subjects related with farming frameworks [32]. In turn, the increased concerns with sustainability and new frameworks brought about by innovation are feeding hopes to find new solutions for the problems related with soil pollution.

However, it is important to be aware that the characteristics of farms and their respective external conditions/environments diverge between countries, regions and locals [33]. On the other hand, the perception and the importance given by the several stakeholders to the problems related with sustainable agricultural development are not equal across the world's countries, including differences between even the European member-states [34,35]. Indeed, sometimes, the difficulties to find adjusted solutions for soil pollution stems from the great diversity of realities around the world, including those within the European Union.

One of the greatest environmental problems from agricultural activities is freshwater contamination, namely in regions where there is greater scarcity and/or more demand [36,37]. The big challenge for the future will be to improve the water quality [38], in contexts where there will be pressure from economic contexts (it is important to grow more and more), social dimension (it is expected, for example, that the population lives for longer) and environmental problems (global warming and lack of available and sustainable resources). An optimized model for water management in farms is fundamental to improve the farmers' economic results and to deal with the several problems related with water quality and availability [39].

Another important question is to be aware of the chemical pollutants' lag time in the groundwater context, namely in the case of nitrates and their potential long travel time [40]. Water is a fundamental resource for all global life and its quality will be compromised if the current tendency of water and soil pollution from several socioeconomic activities continues to go on in the future.

\subsection{The Negative Impacts from Agricultural Practices}

The ecological perspective of farms should be integrated jointly with the economic dimension in the framework of the farmers' decisions, namely in those related with agricultural practices [41,42]. The farmers' training and the respective empowerment may bring about important outcomes for agricultural sustainability, namely in regions where agriculture has less dynamics and performance, sometimes because of contextual conditions. Adjusted farm management options may bring important outcomes for sustainable agricultural practices and improve the balance between benefits and losses [4346].

One of the biggest challenges in the reduction of negative impacts from agricultural practices on soil quality is the trade-off between the maximization of the net economic results and the preservation of the environmental standards [47-50]. Vegetative buffer strips, for example, may be an interesting practice towards maintaining the soil and water quality and improving farm incomes [51]. Another alternative is reducing the levels of eutrophication from the phosphorus input, recycling the phosphorus from the water or using algal as fertilizers or biofuel [52], or, even, using organic matter [53-55]. The use of chemical products (fertilizers and crop protection products, for example) in the farming sector, usually brings problems of soil and water pollution, amongst other negative implications. This may be mitigated with more sustainable practices, namely increasing the use of more sustainable inputs.

However, the farmers' decisions are influenced by several factors, including their real perception of the consequences from bad agricultural practices on the environmental quality [56]. In any case, the economic returns are often one of the most important factors that make the difference at the time of 
making decisions and for options chosen by farmers [3]. In fact, in a sector such as agriculture, where the profit margins are often small, the net results between costs and revenues have a determinant weight upon a farm's management.

The multifunctionality of farms is often forgotten and, consequently, the agricultural development is frequently associated with losses in biodiversity, human health and soil quality [57]. Bringing more activities into farms is crucial in order to increase the farmers' income whilst at same time allowing for improvements in the contribution towards environmental preservation. The activities related with tourism developed inside the farms (rural tourism and ecotourism), for example, reduce the length of the agro chains with interesting contributions for the net economic results of the farmers and allow for reductions in the carbon impacts (namely those related with the transportation of agricultural products). The risks for human health from water and soil contamination, namely with heavy metals, is a real concern these days [58]. The multidisciplinary approach of pollution realities from agriculture could provide an interesting contribution to finding adjusted solutions for a tendency verified in these modern times, as a consequence of agricultural transformations [59]. The future is coming and it is important to find urgent solutions, where every science may provide interesting and significant contributions towards the needed solutions.

\section{Stressing the Need for Good Practices for Soil Quality and Their Respective Benefits}

The good practices are always the best way to mitigate the soil pollution [60]. In some contexts, such as in Brazil, where through the concept of agroforestry systems (crop-livestock-forest) and adjusted good practices, it is possible to increase production with less input and less impact on the environment and on society [61]. The incorporation of organic matter into the soil is one of the main drivers to improving soil quality, namely in terms of structure and fertility. The incorporation of crop residues provides an important contribution for the promotion of the levels of soil quality [62]. In fact, the crop residues may repair damages in the soil structure, improve stability, promote water retention and soil fertility [63].

On the other hand, green manure crops are another alternative towards improving the soil quality through good practices having relevant impacts on agricultural contributions for entire sustainability. These crops complemented with adjusted treatments (such as for example broadcasting before harvesting and partial tillage seeding in rice production) may allow for increases in production without compromising the environmental sustainability [64]. Animal manure and the biobased fertilizers may be other relevant alternatives for soil quality improvement/preservation, comparatively to chemical fertilizers [65].

In Europe and China the best agricultural management practices for soil quality are namely crop rotation, manuring and composting, min-till, residue maintenance and Integrated pest and disease management [66]. The diversification of activities within farms appears to be another adjusted good practice for agricultural sustainability [67].

Taking advantage of the circular economy may also be an interesting approach to improve the soil quality, namely by reintroducing algal biomass into agriculture, as a fertilizer, produced from the nutrients lost by the agricultural activities for the freshwater and marine [68]. Of course, the topic of circular economies and questions related to it need special attention and further investigation in future studies. The tillage practices, also, influence the soil quality. In this way, zero tillage appears as a motivating approach towards improving the soil structure with benefits for biological processes and microbial biodiversity [69]. Biochar appears as another more sustainable fertilizer (by mitigating greenhouse gas emissions) and is a promoter of good soil quality [70].

\section{Conclusions}

The main objective of this study was to explore the several interrelationships between the topics soil pollution and agricultural economics in scientific literature, considering the scientific studies available in the Web of Science platform. These studies were first analysed and clustered through 
the VOSviewer software (considering the occurrences of the several terms) and were subsequently further explored through literature review. From the cluster analysis it was possible to find three clusters where the terms with greater occurrences are respectively "problem", "benefit" and "loss". Comparatively with other studies, the research here presented was developed around these three central terms and the respective closeness (relatedness) with the other terms inside each cluster.

The literature review shows that agricultural policies have a determinant role towards improving sustainability in the relationships between soil pollution and agricultural activities. Adjusted plans of design and management of these policies and respective programs are crucial for an effective implementation of these strategies and to achieve the desired objectives. For this, a permanent assessment is essential, as it is equally essential to know the several sources of pollution and the respective reactions to the different strategies of mitigation. Farmer training, empowerment and economic incentives seem to be the preferred policies to improve sustainability in the farming sector. This is important, namely to improve the farmers' perception about the importance of adjusted practices that preserve the environment in conciliation with the economic and social dimensions of the farms. Through the involvement of the several stakeholders present in each region, and by then listening to their opinions and perspectives, this may be a first step in the design of adjusted programs and policies.

Productivity and efficiency are important variables for more sustainable farms, because by improving these two factors it is possible to think in the medium and long-term and consequently reduce the environmental impact from agriculture without compromising the future of the farmers' incomes. Good plans of management may provide an important contribution here, namely those that put together the economic perspective in conjunction with the ecological dimension. Multifunctionality and new more sustainable agricultural practices, could bring about some interesting outcomes, namely those that allow us to reduce the length of the agro chains. The good news in these complex contexts is that there has been a boon of scientific research developed over the last decades in issues related with the several activities implemented in farms.

The main concerns about soil pollution from agricultural activities seem to be with water quality, the soil erosion and the presence of heavy metals in the soil which represent serious risks for human health. Another question is about the focus adopted by the several stakeholders on the relationships between soil pollution and agricultural economics. In fact, it seems that the stakeholders, including researchers, are more focussed upon the problems than on the solutions. It seems that the problems are well identified, now it is important to increase the flow of information about the solutions. In turn, the stakeholders seem to be more engrossed by the losses from soil pollution rather than by the benefits. The populations like to be recognized for their contributions towards better welfare. It is important to stress this and to highlight the benefits from good water and soil quality.

In any case, there are several solutions in order to improve the soil quality, namely in terms of structure, fertilization, biological processes, organic matter and microbial biodiversity, such as, for example: biochar, green manure crops, circular economy, the incorporation of crop residues, reducing tillage practices, animal and biobased fertilizers, crop rotation, crop diversification, manuring and composting, residue maintenance and Integrated pest and disease management. It is worth stressing, however, that local realities around the world are different and the solutions to be adopted need to be conveniently adapted to each case. The research developed over the last few years in this area may and should give crucial insight and support.

Considering the contributions brought about by this study, it will be important to explore in future work how the soil health influences the ecosystem services, considering their importance for an integrated rural development. It will be important, also, to bring more insight about the multifunctional dimensions inside the farms and their importance for sustainability within the agricultural sector and the respective positive externalities for ecosystems and for society. It will be important to further explore the topics related with solutions for soil pollution from agricultural practices, by stressing questions related with the circular economy and assessments based on life cycle methodologies. 
Despite the restrictions imposed on this study, it brings to the fore interesting insights for the several stakeholders, including farmers, policymakers and researchers. In fact, the main gaps from the literature associated with the topics of soil pollution and agricultural were emphasized. On the other hand, some considerations for policy adjustment were provided, as well as some suggestions for good farming practices.

Funding: This work is financed by national funds through FCT—Fundação para a Ciência e Tecnologia, I.P., under the project UID/Multi/04016/2019. Furthermore we would like to thank the Instituto Politécnico de Viseu and CI\&DETS for their support. This work is supported by national funds, through the FCT-Portuguese Foundation for Science and Technology under the project UID/SOC/04011/2019.

Conflicts of Interest: The author declares no conflict of interest.

\section{References}

1. Denver, S.; Christensen, T. Organic food and health concerns: A dietary approach using observed data. NJAS Wagening. J. Life Sci. 2015, 74, 9-15. [CrossRef]

2. Donaldson, A.B.; Flichman, G.; Webster, J.P.G. Integrating agronomic and economic models for policy analysis at the farm level: The impact of CAP reform in two European regions. Agric. Syst. 1995, 48, 163-178. [CrossRef]

3. Rashford, B.S.; Walker, J.A.; Bastian, C.T. Economics of Grassland Conversion to Cropland in the Prairie Pothole Region. Conserv. Biol. 2011, 25, 276-284. [CrossRef] [PubMed]

4. Web of Science. Web of Science Platform. Available online: https://apps.webofknowledge.com/WOS_ GeneralSearch_input.do?product=WOS\&search_mode=GeneralSearch\&SID=F3thLlaCM72Vzo9yfmp\& preferencesSaved $=($ accessed on 30 January 2018).

5. VOSviewer. VOSviewer-Visualizing Scientific Landscapes. Available online: http://www.vosviewer.com// (accessed on 26 November 2018).

6. Van Eck, N.J.; Waltman, L. VOSviewer Manual 2018. Available online: https://www.vosviewer.com/ documentation/Manual_VOSviewer_1.6.8.pdf (accessed on 26 November 2018).

7. Martinho, V.J.P.D. Interrelationships between renewable energy and agricultural economics: An overview. Energy Strat. Rev. 2018, 22, 396-409. [CrossRef]

8. Abler, D. Economic evaluation of agricultural pollution control options for China. J. Integr. Agric. 2015, 14, 1045-1056. [CrossRef]

9. Brackin, R.; Atkinson, B.S.; Sturrock, C.J.; Rasmussen, A. Roots-eye view: Using microdialysis and microCT to non-destructively map root nutrient depletion and accumulation zones. Plant Cell Environ. 2017, 40, 3135-3142. [CrossRef] [PubMed]

10. Brown, L.E.; Mitchell, G.; Holden, J.; Folkard, A.; Wright, N.; Beharry-Borg, N.; Berry, G.; Brierley, B.; Chapman, P.; Clarke, S.J.; et al. Priority water research questions as determined by UK practitioners and policy makers. Sci. Total Environ. 2010, 409, 256-266. [CrossRef]

11. Lederer, J.; Ogwang, F.; Karungi, J. Knowledge identification and creation among local stakeholders in CDM waste composting projects: A case study from Uganda. Resour. Conserv. Recycl. 2017, 122, 339-352. [CrossRef]

12. Lahori, A.H.; Zhanyu, G.; Zengqiang, Z.; Ronghua, L.; Mahar, A.; Awasthi, M.K.; Feng, S.; Sial, T.A.; Kumbhar, F.; Ping, W.; et al. Use of Biochar as an Amendment for Remediation of Heavy Metal-Contaminated Soils: Prospects and Challenges. Pedosphere 2017, 27, 991-1014. [CrossRef]

13. Luo, C.; Chen, L.; Zhao, H.; Guo, S.; Wang, G. Challenges facing socioeconomic development as a result of China's environmental problems, and future prospects. Ecol. Eng. 2013, 60, 199-203. [CrossRef]

14. Vazquez-Nunez, E.; Pena-Castro, J.M.; Fernandez-Luqueno, F.; Cejudo, E.; de la Rosa-Alvarez, M.G.; Garcia-Castaneda, M.C. A Review on Genetically Modified Plants Designed to Phytoremediate Polluted Soils: Biochemical Responses and International Regulation. Pedosphere 2018, 28, 697-712. [CrossRef]

15. Willis, C. Economics. Res. J. Water Pollut. Control Fed. 1990, 62, 318-320.

16. Bonnieux, F.; Carpentier, A.; Weaver, R. Reducing soil contamination: Economic incentives and potential benefits. Agric. Ecosyst. Environ. 1998, 67, 275-288. [CrossRef]

17. Martinho, V.J.P.D. Output Impacts of the Single Payment Scheme in Portugal: A Regression with Spatial Effects. Outlook Agric. 2015, 44, 109-118. [CrossRef] 
18. Evans, R. Reducing soil erosion and the loss of soil fertility for environmentally-sustainable agricultural cropping and livestock production systems. Ann. Appl. Biol. 2005, 146, 137-146. [CrossRef]

19. Horan, R.D.; Ribaudo, M.O. Policy objectives and economic incentives for controlling agricultural sources of nonpoint pollution. J. Am. Water Resour. Assoc. 1999, 35, 1023-1035. [CrossRef]

20. Smethurst, P.J.; Petrone, K.C.; Langergraber, G.; Baillie, C. Plantation buffers for streams in agricultural catchments: Developing the knowledge base for natural resource managers and farm-foresters. In Proceedings of the 18th world IMACS Congress and MODSIM09 International Congress on Modelling and Simulation: Interfacing Modelling and Simulation with Mathematical and Computational Sciences, Cairns, Australia, 13-17 July 2009; pp. 2436-2442.

21. Iho, A.; Ahlvik, L.; Ekholm, P.; Lehtoranta, J.; Kortelainen, P. Optimal Phosphorus Abatement Redefined: Insights from Coupled Element Cycles. Ecol. Econ. 2017, 137, 13-19. [CrossRef]

22. Janssen, S.; Louhichi, K.; Kanellopoulos, A.; Zander, P.; Flichman, G.; Hengsdijk, H.; Meuter, E.; Andersen, E.; Belhouchette, H.; Blanco, M.; et al. A Generic Bio-Economic Farm Model for Environmental and Economic Assessment of Agricultural Systems. Environ. Manag. 2010, 46, 862-877. [CrossRef]

23. Gibbons, J.M.; Williamson, J.C.; Williams, A.P.; Withers, P.J.A.; Hockley, N.; Harris, I.M.; Hughes, J.W.; Taylor, R.L.; Jones, D.L.; Healey, J.R. Sustainable nutrient management at field, farm and regional level: Soil testing, nutrient budgets and the trade-off between lime application and greenhouse gas emissions. Agric. Ecosyst. Environ. 2014, 188, 48-56. [CrossRef]

24. Govindasamy, R.; Cochran, M.; Buchberger, E. Economic-Implications of Phosphorus Loading Policies for Pasture Land Applications of Poultry Litter. Water Resour. Bull. 1994, 30, 901-910. [CrossRef]

25. Haruvy, N.; Hadas, A.; Hadas, A. Cost assessment of various means of averting environmental damage and groundwater contamination from nitrate seepage. Agric. Water Manag. 1997, 32, 307-320. [CrossRef]

26. Hong-Yun, H.; Lian-Ge, Z. Farmers' Character and Behavior of Fertilizer Application-Evidence from a Survey of Xinxiang County, Henan Province, China. Agric. Sci. China 2009, 8, 1238-1245.

27. Van Vuuren, W.; Giraldez, J.C.; Stonehouse, D.P. The social returns of agricultural practices for promoting water quality improvement. Can. J. Agric. Econ. Rev. Can. Agroecon. 1997, 45, 219-234. [CrossRef]

28. Westra, J.V.; Zimmerman, J.K.H.; Vondracek, B. Bioeconomic analysis of selected conservation practices on soil erosion and freshwater fisheries. J. Am. Water Resour. Assoc. 2005, 41, 309-322. [CrossRef]

29. Hediger, W. Sustainable farm income in the presence of soil erosion: An agricultural Hartwick rule. Ecol. Econ. 2003, 45, 221-236. [CrossRef]

30. Li, H.; Cruse, R.M.; Bingner, R.L.; Gesch, K.R.; Zhang, X. Evaluating ephemeral gully erosion impact on Zea mays L. yield and economics using AnnAGNPS. Soil Tillage Res. 2016, 155, 157-165. [CrossRef]

31. Kamel, S.; Dahl, C. The economics of hybrid power systems for sustainable desert agriculture in Egypt. Energy 2005, 30, 1271-1281. [CrossRef]

32. Lichtenberg, E.; Shortle, J.; Wilen, J.; Zilberman, D. Natural Resource Economics and Conservation: Contributions of Agricultural Economics and Agricultural Economists. Am. J. Agric. Econ. 2010, 92, 469-486. [CrossRef]

33. Sharma, S.; Manhas, S.S.; Sharma, R.M.; Lohan, S.K. Potential of Variable Rate Application Technology in India. AMA Agric. Mech. Asia Afr. Lat. Am. 2014, 45, 74-81.

34. Varallyay, G.; Buzas, I.; Kadar, I.; Nemeth, T. New Plant Nutrition Advisory System in Hungary. Commun. Soil Sci. Plant Anal. 1992, 23, 2053-2073. [CrossRef]

35. Ungureanu, G.; Ignat, G.; Boghita, E.; Costuleanu, L.; Vintu, C.R.; Bodescu, D.; Bejinariu, C. Good Management Practices in Managing the Most Important Factors to Ensure Dureble Soil Quality. Rev. Chim. 2017, 68, 2350-2357.

36. Bouwer, H. Integrated water management for the 21st century: Problems and solutions. J. Irrig. Drainage Eng. ASCE 2002, 128, 193-202. [CrossRef]

37. Bouwer, H. Integrated water management for the 21st century: Problems and Solutions. J. Food Agric. Environ. 2003, 1, 118-127. [CrossRef]

38. Zia, H.; Harris, N.R.; Merrett, G.V.; Rivers, M.; Coles, N. The impact of agricultural activities on water quality: A case for collaborative catchment-scale management using integrated wireless sensor networks. Comput. Electron. Agric. 2013, 96, 126-138. [CrossRef]

39. Dinar, A.; Zilberman, D. The Economics of Resource-Conservation, Pollution-Reduction Technology Selection-The Case of Irrigation Water. Resour. Energy 1991, 13, 323-348. [CrossRef] 
40. Wang, L.; Butcher, A.S.; Stuart, M.E.; Gooddy, D.C.; Bloomfield, J.P. The nitrate time bomb: A numerical way to investigate nitrate storage and lag time in the unsaturated zone. Environ. Geochem. Health 2013, 35, 667-681. [CrossRef]

41. Botterweg, P.; Leek, R.; Romstad, E.; Vatn, A. Erosion control under different political and economic conditions. Soil Tillage Res. 1998, 46, 31-40. [CrossRef]

42. Prato, T.; Fulcher, C. Protecting soil and water resources through multiobjective decision making. In Multiple Objective Decision Making for Land, Water and Environmental Management; El Swaify, S.A., Yakowitz, D.S., Eds.; Lewis Publishers: Boston, MA, USA, 1998; pp. 385-394.

43. Pimentel, D. Ethanol Fuels-Energy Security, Economics, and the Environment. J. Agric. Environ. Ethics 1991, 4, 1-13. [CrossRef]

44. Del Prado, A.; Scholefield, D. Use of SIMS(DAIRY) modelling framework system to compare the scope on the sustainability of a dairy farm of animal and plant genetic-based improvements with management-based changes. J. Agric. Sci. 2008, 146, 195-211. [CrossRef]

45. Naramngam, S.; Tong, S.T.Y. Environmental and economic implications of various conservative agricultural practices in the Upper Little Miami River basin. Agric. Water Manag. 2013, 119, 65-79. [CrossRef]

46. Kaur, J.; Mahal, S.S. Influence of paddy straw mulch on crop productivity and economics of bed and fiat sown wheat (Triticum aestivum) under different irrigation schedules. J. Environ. Biol. 2017, 38, 243-250. [CrossRef]

47. Yakowitz, D.; Stone, J.; Lane, L.; Heilman, P.; Masterson, J.; Abolt, J.; Imam, B. A Decision-Support System for Evaluating the Effects of Alternative Farm-Management Systems on Water-Quality and Economics. Water Sci. Technol. 1993, 28, 47-54. [CrossRef]

48. Wei, Y.; Chen, D.; Hu, K.; Willett, I.R.; Langford, J. Policy incentives for reducing nitrate leaching from intensive agriculture in desert oases of Alxa, Inner Mongolia, China. Agric. Water Manag. 2009, 96, 1114-1119. [CrossRef]

49. Pena-Haro, S.; Llopis-Albert, C.; Pulido-Velazquez, M.; Pulido-Velazquez, D. Fertilizer standards for controlling groundwater nitrate pollution from agriculture: El Salobral-Los Llanos case study, Spain. J. Hydrol. 2010, 392, 174-187. [CrossRef]

50. Song, J.; Gramig, B.M.; Cibin, R.; Chaubey, I. Integrated Economic and Environmental Assessment of Cellulosic Biofuel Production in an Agricultural Watershed. BioEnergy Res. 2017, 10, 509-524. [CrossRef]

51. Rein, F.A. An economic analysis of vegetative buffer strip implementation-Case study: Elkhorn Slough, Monterey Bay, California. Coast. Manag. 1999, 27, 377-390. [CrossRef]

52. Sharpley, A.; Wang, X. Managing agricultural phosphorus for water quality: Lessons from the USA and China. J. Environ. Sci. 2014, 26, 1770-1782. [CrossRef] [PubMed]

53. Whalen, J.K.; Chang, C.; Clayton, G.W. Cattle manure and lime amendments to improve crop production of acidic soils in northern Alberta. Can. J. Soil Sci. 2002, 82, 227-238. [CrossRef]

54. Ventrella, D.; Virzi, N.; Intrigliolo, F.; Palumbo, M.; Cambrea, M.; Platania, A.; Sciacca, F.; Licciardello, S.; Troccoli, A.; Russo, M.; et al. Environmental effectiveness of GAEC cross-compliance standard 2.1 "Maintaining the level of soil organic matter through management of stubble and crop residues" and economic evaluation of the competitiveness gap for farmers. Ital. J. Agron. 2015, 10, 697. [CrossRef]

55. Shivran, A.C.; Jat, N.L.; Singh, D.; Rajput, S.S. Influence of integrated nutrient management on yield, quality and economics of cumin (Cuminum cyminum) production under semi-arid conditions. Indian J. Agric. Sci. 2017, 87, 29-35.

56. Schlapp, J.; Schreider, S. Survey of Farmer Management of Phosphorus Application in the Hopkins River Catchment, for Use in Game-theoretic Modeling. In Proceedings of the MODSIM 2007: International Congress on Modelling and Simulation: Land, Water and Environmental Management: Integrated Systems for Sustainability; Oxley, L., Kulasiri, D., Eds.; University of Canterbury: Christchurch, New Zealand, 2007; pp. 2361-2367.

57. DeLonge, M.S.; Miles, A.; Carlisle, L. Investing in the transition to sustainable agriculture. Environ. Sci. Policy 2016, 55, 266-273. [CrossRef]

58. Sarwar, N.; Imran, M.; Shaheen, M.R.; Ishaque, W.; Kamran, M.A.; Matloob, A.; Rehim, A.; Hussain, S. Phytoremediation strategies for soils contaminated with heavy metals: Modifications and future perspectives. Chemosphere 2017, 171, 710-721. [CrossRef]

59. Burkart, M.R. Diffuse pollution from intensive agriculture: sustainability, challenges, and opportunities. Water Sci. Technol. 2007, 55, 17-23. [CrossRef] [PubMed] 
60. Martinho, V.J.P.D. Best management practices from agricultural economics: Mitigating air, soil and water pollution. Sci. Total Environ. 2019, 688, 346-360. [CrossRef] [PubMed]

61. Costa, M.P.; Schoeneboom, J.C.; Oliveira, S.A.; Vinas, R.S.; de Medeiros, G.A. A socio-eco-efficiency analysis of integrated and non-integrated crop-livestock-forestry systems in the Brazilian Cerrado based on LCA. J. Clean. Prod. 2018, 171, 1460-1471. [CrossRef]

62. Bechini, L.; Costamagna, C.; Zavattaro, L.; Grignani, C.; Bijttebier, J.; Ruysschaert, G. Barriers and drivers towards the incorporation of crop residue in the soil. Analysis of Italian farmers' opinion with the theory of planned behaviour. Ital. J. Agron. 2015, 10, 178-184. [CrossRef]

63. Stan, V.; Fintineru, G.; Mihalache, M. Multicriteria Analysis of the Effects of Field Burning Crop Residues. Notulae Botanicae Horti Agrobotanici Cluj-Napoca 2014, 42, 255-262. [CrossRef]

64. Jeon, W.T.; Choi, B.; Abd El-Azeem, S.A.M.; Ok, Y.S. Effect of different seeding methods on green manure biomass, soil properties and rice yield in rice-based cropping systems. Afr. J. Biotechnol. 2011, 10, 2024-2031.

65. Vaneeckhaute, C.; Ghekiere, G.; Michels, E.; Vanrolleghem, P.A.; Tack, F.M.G.; Meers, E. Assessing Nutrient Use Efficiency and Environmental Pressure of Macronutrients in Biobased Mineral Fertilizers: A Review of Recent Advances and Best Practices at Field Scale. In Advances in Agronomy; Sparks, D.L., Ed.; Elsevier: Amsterdam, The Netherlands, 2014; Volume 128, pp. 137-180.

66. Barao, L.; Alaoui, A.; Ferreira, C.; Basch, G.; Schwilch, G.; Geissen, V.; Sukkel, W.; Lemesle, J.; Garcia-Orenes, F.; Morugan-Coronado, A.; et al. Assessment of promising agricultural management practices. Sci. Total Environ. 2019, 649, 610-619. [CrossRef]

67. Benbi, D.K. Carbon footprint and agricultural sustainability nexus in an intensively cultivated region of Indo-Gangetic Plains. Sci. Total Environ. 2018, 644, 611-623. [CrossRef]

68. Alobwede, E.; Leake, J.R.; Pandhal, J. Circular economy fertilization: Testing micro and macro algal species as soil improvers and nutrient sources for crop production in greenhouse and field conditions. Geoderma 2019, 334, 113-123. [CrossRef]

69. Torabian, S.; Farhangi-Abriz, S.; Denton, M.D. Do tillage systems influence nitrogen fixation in legumes? A review. Soil Tillage Res. 2019, 185, 113-121. [CrossRef]

70. Kavitha, B.; Reddy, P.V.L.; Kim, B.; Lee, S.S.; Pandey, S.K.; Kim, K.-H. Benefits and limitations of biochar amendment in agricultural soils: A review. J. Environ. Manag. 2018, 227, 146-154. [CrossRef] [PubMed] 